\begin{tabular}{l|c|c|}
\hline DE & DE GRUYTER \\
$\mathrm{G}$ & EPEN \\
& DOI 10.1515/ethemes-2016-0016
\end{tabular}

\title{
MEASURING THE LEVEL OF COMPETITION ON THE SERBIAN MOBILE TELECOMMUNICATIONS MARKET ${ }^{*}$
}

\author{
Zorana Kostić \\ University of Nis, Faculty of Economics, Republic of Serbia \\ \zoksinis@gmail.com
}

Boban Stojanović

University of Nis, Faculty of Economics, Republic of Serbia

$\bowtie$ boban.stojanovic@eknfak.ni.ac.rs

\section{Snežana Radukić}

University of Nis, Faculty of Economics, Republic of Serbia $\bowtie$ snezana.radukic@eknfak.ni.ac.rs

UDC

621.395 .72

$1.5: 339.1(4$

97.11)

Original

scientific

paper

\begin{abstract}
The starting hypothesis is that the market structure to a large extent determines the conduct and the level of the achieved performance of economic entities. The aim of this paper is to determine the theoretical and empirical correlation between market structure, conduct, and performance of economic entities. The paper provides an analytical overview of the mobile telecommunications market in the Republic of Serbia. By using different indicators (the Concentration ratio, the HHI, the Lorenz curve, and the Gini coefficient), the supply concentration in this market is measured and the nature of competition is analysed. By using statistical methods (correlation and simple linear regression analysis), the correlation between the variables, which confirmed the existence of a strong positive correlation between the degree of supply concentration on the market and the level of achieved performance is examined.
\end{abstract}

Received: 21.01.2016. Accepted: 03.10.2016.
Keywords: market share, supply concentration, SCP paradigm, the paradigm of efficiency, mobile telecommunications

JEL classification: C10, D43, L13, L96

\footnotetext{
* The paper is part of the Project No. 179066 and 44007 funded by the Ministry of Education, Science, and Technological Development of the Republic of Serbia.
} 


\section{Introduction}

Theoretical insights and empirical material have pointed to the interdependence of market structure, conduct, and performance of business entities. The emphasised market concentration determines the operations of market actors. It is economically expedient to emphasise the complexity of the correlation between the conduct of business entities and the level of achieved performance. This complexity is complemented by the market environment and the specifics of the industry in which business entities are trying to achieve their objective function.

The market structure involves the totality of relationships and the complexity of the relationship between supply and demand. One of the basic features of market structure is the degree of concentration. To analyse the nature of the market structure, generally accepted indicators of supply concentration (n-firm concentration ratio, CRn, the Herfindahl-Hirschman Index, HHI, the Lorenz curve, and Gini coefficient) are used. Taking into account all the advantages and disadvantages of the abovementioned indicators, we conducted an analysis of the situation in the mobile telecommunications market in the Republic of Serbia, and tried to project possible changes in the future. Detailed analysis of the market structure of an individual market should take into account all its specifics. Some of the specifics of this market are the existence of a regulatory framework, institutional infrastructure, the conditions for market liberalisation, and penetration exceeding $100 \%$ (the number of mobile phone users exceeds the total number of people, so that it can be said that these are products/services that foster demand).

The structure of the paper, in addition to the introduction and conclusion, contains four parts. The second part of the paper includes the theoretical basis of mutual dependence of market structure, conduct, and performance of business entities. The third part focuses on the critical analysis of the SCP paradigm, through comparison with the efficiency paradigm, which is an alternative theoretical concept. The research methodology is given in the fourth part of the paper. The fifth part of the paper summarizes the results obtained during the research.

\section{Theoretical Basis of the Structure-Conduct-Performance Paradigm}

The structure-conduct-performance paradigm (the SCP paradigm) is an analytical framework that establishes a causal relationship between market structure, conduct, and performance of a company. The market in which business entities operate affects the conduct of economic actors, which further determines the level and the quality of their performance. A large number of 
studies have pointed to a positive correlation between the degree of supply concentration and the average profit rate in the industry. Higher supply concentration results in a higher average profit rate and vice versa (Bain, 1951).

The market structure, as the first element of the paradigm, includes the variables that are relatively stable over time. The number of participants in the supply and demand side, the supply and demand concentration, the degree of differentiation of products or services, and the existence of entry barriers are some of the criteria for the market classification. These factors affect the degree of the market deviation from the perfect competition conditions. The conduct of a company, or the manner in which buyers and sellers react, is the second element of this paradigm. Some of the most important determinants affecting the conduct of a company are: business goals, pricing, product design, research and development, agreements among companies, and business associations. The third element of the SCP paradigm is the performance, with different indicators being used as a measure of profitability. Variables that are commonly considered are: the price level, growth, quality of products and services, allocative and productive efficiency, and technical progress (Lipczynski at al., 2009). Taking into account the abovementioned elements of the SCP paradigm, one should not ignore the impact of the public policy on the complexity of the relationship between the elements.

Figure 1 Schematic Diagram of the Structure-Conduct-Performance Paradigm

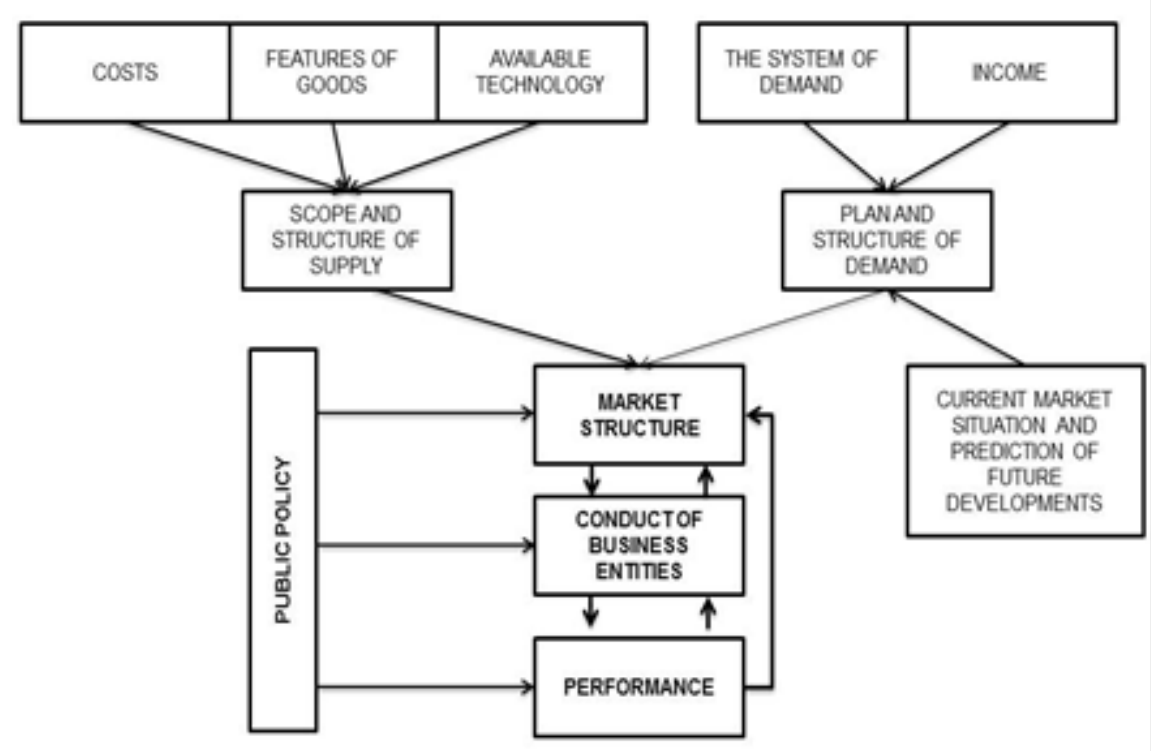

Source: Authors' systematisation according to Stojanović, B. (2012).Mikroekonomija. Niš: Ekonomskifakultet. 
The relationship between structure and performance in this paradigm is derived from the microeconomic perfect competition model. The perfect competition model is a static model that views competition in the context of the market equilibrium. In the long run, perfectly competitive markets will result in the optimal allocation of resources in the economy (McWilliams \& Smart, 1993). According to the dynamic competition, the market is the configuration of decisions made by consumers, entrepreneurs, and owners of resources, and the existence of monopoly is only a temporary market structure. This is because the competition is driven by innovation, i.e. the introduction of new products and processes, conquering new markets, the emergence or reorganisation of existing production arrangements. Innovation replaces old products and production processes by new ones. A successful innovator is rewarded with the monopoly status and the monopoly profit in a certain period of time. However, during the market competition, business entities often erode the monopoly status and profit. Alternatively, another innovator can, in the new manufacturing process, make the previous innovation obsolete. The dynamic competition concept is characterised by the inability to achieve a stable and long-run equilibrium. The main reasons for this are primarily reflected in asymmetric information and insufficient knowledge of economic agents (Lipczynski at al., 2005).

The basic principle of the SCP paradigm is that the economic performance of the industry is a function of conduct of agents in the industry, which, in turn, is a function of market structure. The SCP paradigm emphasises that the structural characteristics of the market, especially the concentration of companies, the degree of entry barriers and their mobility, have a significant impact on the ability of companies to raise prices above the competition within the industry. The absence of entry barriers prevents the existence of monopoly profit and contributes to the achievement of equilibrium. Accordingly, the structural characteristics can determine the potential performance of individual companies (McWilliams \& Smart, 1993).

Implementation of the strategy of mergers and acquisitions of companies is a direct application of the SCP paradigm in practice. One of the main causes of the acquisition is reflected in the structural characteristics of a particular market. Mergers and acquisitions of companies can be a direct function of specific entry barriers. Specifically, increased concentration and entry costs are associated with the need to diversify operations.

The SCP paradigm rests on the assumption that a higher concentration on the market results in higher profit for the company. When several companies cover a large part of the market share, it can encourage open market competition. The existence of the monopoly structure results in higher profit, regardless of efficiency. A number of studies have confirmed a significant positive correlation between market concentration and the level of performance (Samad, 2008). However, the results of a large number of empirical studies, 
conducted in the second half of the 20th century, are contradictory. Relying on the relationship between the size of the company (as a measure of market structure) and the level of profit rate (as a measure of performance), it was found that small or medium-sized businesses were among the most profitable 10 , 50 , or 100 , not the large ones. SCP paradigm has certain drawbacks that limit their application in practice: the level of analysis, the use of static analysis and reliance on entry barriers as key determinants of profitability.

\section{The Structure-Conduct-Performance Paradigm versus the Efficiency Paradigm}

The abovementioned shortcomings of the SCP paradigm have given rise to the need for its critical reassessment. One of the alternative concepts to the SCP paradigm is the efficiency paradigm (McWilliams \& Smart, 1993). According to this paradigm, "the concentration is not a random event, but the result of superior efficiency of leading companies" (Smirlock, 1985). Companies that have a comparative advantage in the production occupy a larger market share, which makes the market more concentrated. In this way, the efficiency of the leading companies leads to their increased market share in terms of concentration, which is in positive correlation with the level of achieved performance (Samad, 2008). The efficiency paradigm views competition as a process that generates efficient performance.

Table 1 The Key Determinants of the Two Paradigms

\begin{tabular}{l|r}
\hline \multicolumn{1}{c|}{ The efficiency paradigm } & The SCP paradigm \\
\hline $\begin{array}{l}\text { Markets are dynamic } \\
\text { Competition is a process }\end{array}$ & $\begin{array}{r}\text { Markets are static } \\
\text { Competition is a state }\end{array}$ \\
$\begin{array}{l}\text { Achieving above-average profit does not } \\
\text { depend on entry barriers }\end{array}$ & $\begin{array}{r}\text { on entry barriers } \\
\text { Analysis of company resources }\end{array}$ \\
$\begin{array}{l}\text { Longitudinal analysis } \\
\text { Profit determines performance }\end{array}$ & $\begin{array}{r}\text { Analysis of industrial structure } \\
\text { Crosector analysis }\end{array}$ \\
\end{tabular}

Source:McWilliams, A. \&L. D. Smart (1993). Efficiency v. Structure - Conduct

- Performance: Implications for Strategy Research and Practice. Journal of Management,doi: 10.1177/014920639301900105

Table 1 shows the key determinants of the analysed paradigms. The SCP paradigm assumes that the competition is a state in the static market, and that the achievement of above-average profit depends on entry barriers. According 
to the SCP paradigm, the analysis of market structure is crucial, and performance is defined by the efficient allocation of resources and maximisation of social welfare. On the other hand, according to the efficiency paradigm, the markets are dynamic and require longitudinal analysis. Achieving aboveaverage profit does not depend on the existence of entry barriers, while the focus of the analysis shifts from the industrial structure to demand and resources. The level of profit determines the level and quality of performance. Understanding competition as a process allows one to acknowledge that the achievement of above-average profit is possible in a competitive environment. (McWilliams \& Smart, 1993).

In addition, entry barriers are not necessary for the realisation of excess profit. Under conditions of static equilibrium there is not above-average profit. Considered as a process, competition ensures that prices will move towards a level appropriate to the perfect competition conditions, but that it will never reach that level. Consequently, the profit will be moving to a normal level, but those companies that are better in anticipating changes in demand and technology will be able to earn the above-average profit. Achieving aboveaverage profit gives a signal to other companies to redistribute resources and take advantage of changes in demand and technology. The existence of aboveaverage profit motivates the entry of new companies into the market (McWilliams \& Smart, 1993)..

Both paradigms recognise the importance of the ability of companies to take advantage of economies of scale and product differentiation. However, they differ in their view of the relationship between market structure and performance. The SCP paradigm assumes a direct relationship among market structure, conduct, and performance, while the efficiency paradigm assumes that markets are competitive, regardless of their structure. Furthermore, paradigms differ in respect of the understanding of the competition. The SCP paradigm views competition in terms of achieving equilibrium in a static environment, while the efficiency paradigm regards competition as a process in a dynamic environment. The SCP paradigm attaches the greatest importance to the structure in achieving competitive advantage. However, the focus on structure can lead to unreasonable investment. The SCP paradigm assumes that there is an optimal structure of the industry, which will allow companies to achieve a sustainable competitive advantage (McWilliams \& Smart, 1993).

\section{Research Methodology}

Based on the available information, the starting hypothesis in this research is that the market structure to a large extent determines the conduct and the level of the achieved performance of business entities. For the purpose of empirical testing of the theoretical knowledge, based on the example of the mobile 
telecommunications market in the Republic of Serbia, statistical methods, linear correlation and regression analyses are used. This research relied on Regulatory Agency for Electronic Communications and Postal Services (RATEL), as well as the financial statements of the mobile operators.

Recognising the fact that, in performing their business activities, mobile operators seek to maximize their objective function (profit), the modeling was based on the following starting assumptions: 1) market share of the operator is a function of the number of users, and the number of users is directly proportional to the number of new users on the market and the number of users who move from other networks, and in inverse proportion to the number of users who leave the market; 2) the number of users is equal to the number of phone numbers (sim cards), because each number is unique; 3 ) one user can have multiple numbers of different operators.

In an effort to carry out a detailed analysis of the competition, and measure the supply concentration in this market, several indicators are used: the concentration ratio of the three leading companies, $\mathrm{CR}_{3}$, the HerfindahlHirschman Index, the HHI, the Lorenz curve, and the Gini coefficient. By using a statistical method, correlation analysis, we examined the correlation between: the market share of the operator and the share the operator has in the total revenue from mobile telecommunications in the period from 2008 to 2013. After the correlation analysis, the regression analysis of the same variables was performed. The aim of the regression analysis was to determine how a percentage increase per unit in the value of the operator's market share affects the change in the operator's share in the total revenue from mobile telecommunications.

\section{Research results and Discussion}

The mobile telecommunications market in the Republic of Serbia is characterised by oligopoly market structure. In oligopoly market structure, there are only a few sellers, who offer similar or identical products, and who have limited market power. In the mobile telecommunications market of Serbia, there are three participants: Telecommunications Company Telekom Serbia a.d. Mobile Telephony of Serbia MTS, Telenor d.o.o., and Vip Mobile d.o.o. The analysis of the level of supply concentration on the mobile telecommunications market of Serbia shows the extent to which the total supply volume is concentrated in a small number of companies. For the purpose of adequate analysis of the market structure, several indicators of supply concentration are used.

$\mathrm{N}$-firm concentration ratio of leading companies, $\mathrm{CRn}$, is an indicator that is used to measure market structure. The degree of market concentration, 
measured via CR3 indicator, shows the cumulative share of the three leading operators in the relevant mobile telecommunications market in Serbia. To determine the degree of supply concentration, the focus has been on the market share of individual participants. In this regard, the CR3 indicator shows which portion of the total number of users on the observed market belongs to mobile operators that operate in the Serbian market. In the present case, the concentration ratio of three companies can be calculated by using the following expression:

$$
C R_{3}=X_{1}+X_{2}+X_{3}=\sum_{i=1}^{3} X_{3}
$$

where $\mathrm{Xi}$ is the market share of companies, which can be obtained by using the following form:

$$
X_{i}=\frac{q i}{Q} * 100(2)
$$

where qi is the total number of users of the mobile operator $\mathrm{i}$, and Q is the total number of mobile phone users on the market.

Table 2 Measuring Supply Concentration by Using the Concentration Ratio $\mathbf{C R}_{3}$

\begin{tabular}{lccc}
\hline Mobile operator & Number of users $q i$ & Market share $\mathrm{X}_{\mathrm{i}}$ & $\begin{array}{c}\text { Concentration ratio } \\
\mathrm{CR}\end{array}$ \\
\hline Telekom Serbia & 4.121 .600 & $44,8 \%$ & 44,8 \\
Telenor & 3.063 .600 & $33,3 \%$ & 78,1 \\
Vip mobile & 2.014 .800 & $21,9 \%$ & $\left(\mathrm{CR}_{3}\right) 100$ \\
Total: & 9.200 .000 & $100 \%$ & \\
\hline
\end{tabular}

Source: Authors' calculation based on data of Regulatory Agency for Electronic Communications and Postal Services,http://www.ratel.rs

The concentration ratio of the leading companies, theoretically speaking, can have a value ranging from 0 to 100 (Lipczynski et al., 2009). The obtained value of the indicator $\left(\mathrm{CR}_{3}=100\right)$ shows that it is a market where the supply concentration is extremely high. The limit value of concentration ratio in the European Union is 25, and, in the United States, 50. This means that it is considered that there is a high level of supply concentration when this ratio exceeds the value of 25 or 50 . The value of ratio above 50 points represents the existence of a highly concentrated market (Savić, 2000). is 100 .

In general, the aggregate market share of all operators on the mobile market

$$
X_{1}+X_{2}+X_{3}+\ldots+X m=100 \quad m=1,2,3, \ldots
$$


The aggregate number of users of all operators is equal to the total number of users in the market.

$$
K 1+K 2+K 3+\ldots+K m=K
$$

The market share of one operator can be calculated as follows:

$$
\begin{gathered}
K_{1}: X=K: 100 \\
X_{1}=\frac{100 \times K_{1}}{K} ; X_{2}=\frac{100 \times K_{2}}{K} ; \ldots . . X_{m}=\frac{100 \times K_{m}}{K}
\end{gathered}
$$

Our starting point is the function by which the market share of a mobile operator depends on the number of its users, namely:

$$
\begin{gathered}
X=\mathrm{F}(K) \\
X_{1}: X_{2}: X_{3}: \ldots: X_{m}=K_{1}: K_{2}: K_{3}: \ldots K_{m} \\
X_{1}=K_{1} \times z ; X_{2}=K_{2} \times z ; \ldots ; X_{m}=K_{m} \times z \\
100=z \times\left(K_{1}+K_{2}+\cdots+K_{m}\right)=z \times K
\end{gathered}
$$

where $z$ is a constant, equaling $100 / K$.

Table 3 Trends in the Market Share of Operators in the Period from 2008 to 2013

\begin{tabular}{lcccccc}
\hline \multicolumn{1}{c}{ Year } & 2008 & 2009 & 2010 & 2011 & 2012 & 2013 \\
\hline $\begin{array}{l}\text { Total number of users in } \\
\text { million }\end{array}$ & 9,6 & 9,9 & 9,9 & 10,1 & 9,1 & 9,2 \\
$\begin{array}{l}\text { Market share in relation to a total number of users (\%) } \\
\text { Telekom Serbia }\end{array}$ & 58,9 & 59,7 & 56,0 & 53,1 & 45,8 & 44,8 \\
$\begin{array}{l}\text { Telenor } \\
\text { Vip Mobile }\end{array}$ & 31,9 & 28,7 & 30,3 & 30,8 & 33,9 & 33,3 \\
$\quad$ Total revenue from & 9,1 & 11,6 & 13,7 & 16,1 & 20,3 & 21,9 \\
$\quad$ mobile telephony & & & & & & \\
$\quad$ (in mil. of euros) & 913,4 & 826,7 & 769,2 & 846,7 & 850,0 & 877,7 \\
$\quad$ Share of operators in total revenue from mobile telephony (\%) & \\
Telekom Serbia & 52,1 & 50,7 & 43,7 & 38,8 & 38,1 & 37,0 \\
Telenor & 41,8 & 40,5 & 42,4 & 43,6 & 42,4 & 41,0 \\
Vip Mobile & 6,02 & 8,8 & 13,9 & 17,6 & 19,5 & 22,0 \\
\hline
\end{tabular}

Source: Authors' calculation based on data of Regulatory Agency for Electronic Communications and Postal Services, http://www.ratel.rs

In the reporting period, from 2008 to 2013, a steady increase in the number of users has been recorded, which is primarily the result of growth in demand for this type of service, due to a significant reduction in the price of mobile phone services (due to competition, but also because of the company's 
intentions to take significant market share despite the continuous loss (VIP Mobile), as well as the complete neglect of the use of fixed telephony. So, these are products (services) that foster demand. In the period from 2008 to 2010, the total revenue from the mobile telephony in Serbia decreased. One of the reasons for this may be the impact of the economic crisis, to which the telecommunications market is not immune. Since 2011, this market has been recovered. Judging by operators, a downward trend in the level of market share is seen in the case of one operator (Telekom Serbia). In addition, Telenor has increased their share in the number of users, and decreased share in the total income, while the Vip Mobile recorded a very dynamic growth in both indicators.

The competition in the mobile telecommunications market can be analysed by using the Herfindahl-Hirschman Index (HHI). This index measures the concentration of a specific market. Calculatively speaking, the HHI represents the sum of squares of the share of $n$ companies on the relevant market, and can be expressed as follows (Lipczynski at al., 2009):

$$
H H I=\sum_{i=1}^{n}\left(X_{i}^{2}\right)\left(H H I=\sum_{i=1}^{n}\left(X_{i}^{2}\right)\right.
$$

where $\mathrm{Xi}$ is the market share of an individual company in the total supply on the relevant market:

$$
X_{i}=q i / Q
$$

where $q i$ is the total number of users of the mobile operator $i$, and $Q$ is the total number of mobile phone users on the market. This indicator takes into account the market share of all companies in the industry, and gives special attention to companies with large market share. Theoretically speaking, the HHI can have a value between 0 (perfect competition) to 10000 (monopoly).

Table 4 The Value of the HHI in the Period from 2008 to 2013

\begin{tabular}{lcc}
\hline & & HHI Index \\
(1) 2008 & $(58.93)^{2}+(31.94)^{2}+(9.13)^{2}$ & 4576 \\
(2) 2009 & $(59.7)^{2}+(28.7)^{2}+(11.6)^{2}$ & 4612 \\
(3) 2010 & $56^{2}+(30.3)^{2}+(13.7)^{2}$ & 4241 \\
(4) 2011 & $(53.1)^{2}+(30.8)^{2}+(16.13)^{2}$ & 4028 \\
(5) 2012 & $(45.8)^{2}+(33.9)^{2}+(20.3)^{2}$ & 3658 \\
(6) 2013 & $(44.8)^{2}+(33.3)^{2}+(21.9)^{2}$ & 3596 \\
\hline
\end{tabular}

Source: Authors' calculation based on data of Regulatory Agency for Electronic Communications and Postal Services, http://www.ratel.rs 
We can see the values of the Herfindahl-Hirschman Index in the period from 2008 to 2013 in Graph 1. During the analysed period, the value of the HHI decreased, so it can be concluded that the competition among the participants on the mobile telephony market increased year by year.

\section{Graph 1 The Value of the Herfindahl-Hirschman Index in the Period from 2008 to 2013}

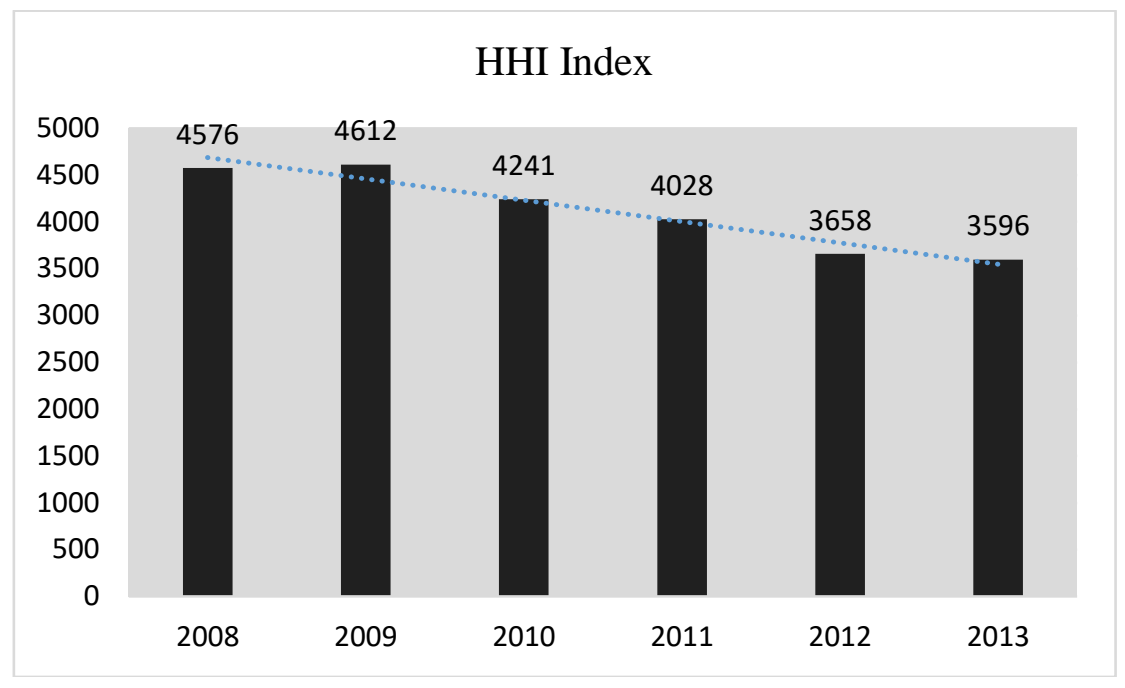

Source: Authors' calculation based on data in Table 4

Bearing in mind that the value of the index was greater than 2000, it can be argued that the observed market is concentrated (Stojanović, 2012, 172). However, the obtained values of the HHI, which is a measure of the dispersion of concentration, points to the fact that the concentration of the observed market decreased. The decrease in the value of the index was under a crucial influence of changes in market share, given that the number of companies on the relevant market remained unchanged.

"The Herfindahl-Hirschman Index has its reciprocal value (1/HHI), which indicates the number of equally large companies in an industry, which could achieve a given value of the Herfindahl-Hirschman Index" (Kostić, 2008, p. 96). In the present case, the reciprocal value of the HHI for the last analysed year (2013) was 0,000278. This suggests that at least two operators with identical market share could achieve the value of HHI of 3596.

The Lorenz curve is a tool for graphical presentation of the level of market concentration and detection of uneven distribution of market share (Lipczynski at al., 2009). Based on the deviation of the Lorenz curve from the curve of equal market share ( $45^{\circ}$ curve), which shows absolutely equal distribution of market share among all participants in the market, uniformity in the distribution of 
market share can be observed. A higher degree of inequality in the distribution of market power exists when the Lorenz curve is farther away from the diagonal line of absolute equality (Stojanović, 2012, 172). In Graph 2, uniformity in the distribution of market share among individual companies in the mobile telecommunications market in Serbia is shown. Abscissa axis lines up companies from smallest to largest (in percentage term). Ordinate axis shows the cumulative market share of companies, ranging from 0 to $100 \%$ of the total supply. Given that the number of companies does not have a decisive role in determining the level of concentration (one company with $100 \%$ market share and ten companies with $10 \%$ market share will be on $45^{\circ}$ curve), the Lorenz curve can be a useful tool in this analysis.

\section{Graph 2 The Lorenz Curve in the Case of Mobile Telecommunications Market}

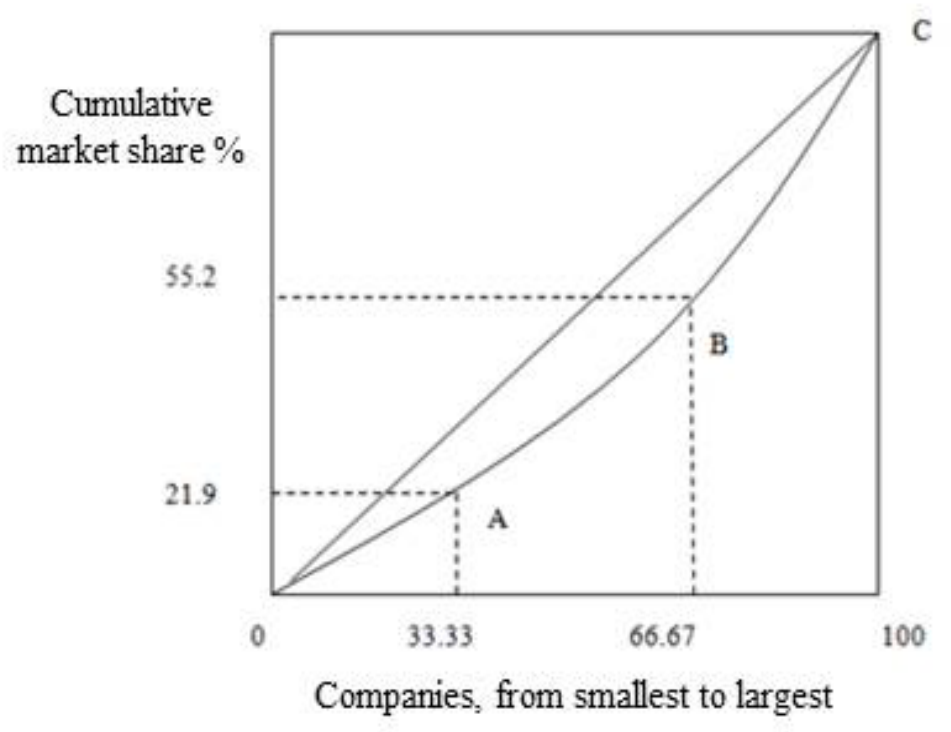

Source: Authors' calculation

The case here refers to the oligopoly market, where there are few companies with the uneven distribution of market share. Point A on the graph shows that one third of the total number of companies occupies $22 \%$ of the market supply, and that two thirds of the total number of companies makes up almost $80 \%$ of the total market supply.

Based on the Lorenz curve graph, we can calculate the Gini coefficient. This numeric indicator describes the curvature of the Lorenz curve. To calculate the Gini coefficient, the following equation can be used (Bajec at al., 2006):

$$
G=\frac{2}{\mu n^{2}} \sum_{I=1}^{n}\left(r_{i}-\frac{n+1}{2}\right) q_{i}
$$


wheren is the number of companies, $\mu$ the average number of users on the mobile telephony market, $r_{i}$ the ranking that a company $i$ has (companies are ranked according to their market share, from smallest to largest) and $q_{i}$ the number of mobile phone users of the company $i$.

The Gini coefficient is a measure of deviation of the Lorenz curve from the line of equal market share. The value of the coefficient of 0 indicates complete equality in the distribution of market share among market participants. On the other hand, if the value of the coefficient approaches 1 , it can be said that there is a market monopoly. This indicator ignores the number of companies on the market and emphasizes the disparity in supply among them.

Table 5 Determination of Supply Concentration by Using the Gini Coefficient

\begin{tabular}{crcc}
\hline Ranking $\mathrm{r}_{\mathrm{i}}$ & Mobile operator & Number of users $\mathrm{q}_{\mathrm{i}}$ & $\left(\mathrm{r}_{\mathrm{i}}-\frac{\mathrm{n}+1}{2}\right) \mathrm{q}_{\mathrm{i}}$ \\
\hline 1 & Vip Mobile & 2.014 .800 & -2.014 .800 \\
2 & Telenor & 3.063 .600 & 0 \\
3 & Telekom Serbia & 4.121 .600 & 4.121 .600 \\
Total: & 9.200 .000 & 2.106 .800 \\
$\mu$ average number of users & 3.066 .666 & \\
\hline
\end{tabular}

Source: Authors' calculation

$$
G=\frac{2}{3.066 .666 * 3^{2}} * 2.106 .800=0,15
$$

The Gini coefficient for this market structure equals 0,15 , which places it in the group of low concentrated markets (Lipczynski et al., 2009).

Bearing in mind the market power and dominance in the market, we will try to determine the existence of participants with significant market power. Mobile operator has significant market power in the relevant market ${ }^{1}$, if it, alone or together with other operators, has a dominant position, i.e. a position that allows it to behave mostly independently from competitors, its subscribers, and, ultimately, consumers. When determining individual significant market power, the following is taken into account in particular: the size of the operator and its competitors, particularly in terms of the number of users and revenue in the relevant market; control over the infrastructure; operator's technological advantage; lack or low level of bargaining power of buyers; easy or privileged

\footnotetext{
1,"Relevant market is a set of products or services which customers consider interchangeable depending on the use, features, and price. It includes the area in which companies offer relevant products and services, where the conditions of competition are homogeneous, and which differs from other areas in respect of these conditions" (Stojanović, 2012, p. 177).
} 
access to equity markets; diversification of products or services; economies of scale; lack of potential competition, and the like. When determining joint market power, the following is taken into account in particular: market saturation; stagnation or moderate growth in demand; low elasticity of demand; product homogeneity; similarity of the cost structure; similarity of market share; lack of technical innovation; lack of bargaining power of buyers; lack of potential competition; the existence of various informal and other links between operators; lack of, or limited space for competitive pricing (Zakon o elektronskim komunikacijama, 2014). If the relevant market (as well as the closely related market) lacks effective competition, it is determined which operator, individually or together with other operators, has significant market power in that market. ${ }^{2}$

One of the fundamental rights of the consumer is the right to choose. This right includes the possibility of choice among a number of products and services, at affordable prices and guaranteed good quality. Consumers have an option to change the operator, while still keeping the mobile phone number. This is a very important mechanism for fostering competition in the telecommunications market. At the end of 2011, 37.037 mobile phone users changed operators and kept the same number. At the end of 2012, the number of users who did that was 114.822. RATEL's data from 2013 shows that there were 200.495 mobile phone users who took advantage of the opportunity to change the operator while keeping the number, which represents about $2 \%$ of the total number of users. In 2013, a trend of returning to the original operator was recorded.

The model started from the function by which the number of users of one operator $(\mathrm{K})$ is in direct proportion to the number of new users in the market (n) and the number of users who move from other networks (b), and inversely proportional to the number of users leaving the market (o). Based on the defined assumptions of the model, the authors found the following formula that, mathematically speaking, can be expressed as follows:

$$
\mathrm{K}=\mathrm{F}(n, b, o)
$$

with market share of the operator defined as:

$$
\begin{gathered}
\mathrm{X}_{1}=\frac{\mathrm{n}_{1}+\mathrm{b}_{1}-\mathrm{o}_{1}}{\mathrm{~K}} \times 100 ; \quad \mathrm{X}_{2}=\frac{\mathrm{n}_{2}+\mathrm{b}_{2}-\mathrm{o}_{2}}{\mathrm{~K}} \times 100 ; \ldots ; \\
X_{m}=\frac{n_{m}+b_{m}-o_{m}}{K} \times 100
\end{gathered}
$$

Taking into account above assumptions, authors define the following: $K_{t}=$ $K_{t-1}+n_{t}-o_{t}$, where a new user can be transferred from other operator's

\footnotetext{
${ }^{2}$ RATEL adopted the Decision on determining nine relevant markets subject to regulations in the
} Republic of Serbia (Službeniglasnik RS, broj 59/11). 
network. If a new user is transferred from another network, then $b_{m}=k_{t}-k_{t-1}$. When $b_{m}>0$, it implies increase in the number of users of a certain operator, and unchanged total number of users on the market. Suppose the ceteris paribus clause applies. If the number of transferred numbers increases by 1 , then the total number of users on the market remains unchanged (if $b+1$, then $K=$ const). If the number of new users on the market increases, then the number of $\mathrm{e}$ transferred numbers is constant (if $K+n$, then $b=$ const). If the number of users who leave the market increases by 1 , the total number of users on the market will decrease by 1 , while the number of transferred users will remain constant (if $K-o$, then $b=$ const).

$$
\lim _{k \rightarrow \infty} F(K)=\infty
$$

Dynamically speaking, in terms of time, the market share is a function of the number of users, which changes at a certain rate over time, which may not be constant. We include the time factor $t$ into the starting function, and get the following function:

$$
X=\mathrm{F}(K, t)
$$

According to the initial assumptions of the model, authors define the rate of change in the market share equals the rate of change in the number of users.

$$
\begin{gathered}
\frac{\Delta X_{t+1}}{X_{t}}=\frac{\Delta K_{t+1}}{K_{t}} \\
\frac{\Delta K_{t+1}}{K_{t}}=\frac{\Delta n_{t+1}}{n_{t}}+\frac{\Delta b_{t+1}}{b_{t}}-\frac{\Delta o_{t+1}}{o_{t}}
\end{gathered}
$$

In terms of technical progress, this leads to the application of innovation, which results in greater differentiation of products and services, offered by companies in the industry. Under such circumstances, it is assumed that the growth rate of new users in the market and the growth rate of transferred users will be greater than the rate of users who leave the market.

Attention should also focus on the achieved performance of business entities. One of the indicators resulting from the research is the average revenue per user. Specifically, when the total revenue from mobile telephony is divided by the number of users of a specific operator, the average revenue per user is obtained. Graph 3 shows the trend of revenue per user for all three operators in the period from 2008 to 2013. Telenor generated the largest revenue per user, while Vip Mobile generated the least revenue per user. However, a growing trend in revenue per user in the case of this operator can be observed. One operator (Telenor) generated above-average revenue per mobile user in the observed period. According to the efficiency paradigm, understanding competition as a process allows one to acknowledge that the generation of above-average profit is possible in a competitive environment. In fact, the 
amount of above-average profit affects capacity building and the entry of new companies in the industry.

Graph 3 Revenue from Mobile Telephony per User in the Period 2008-2013

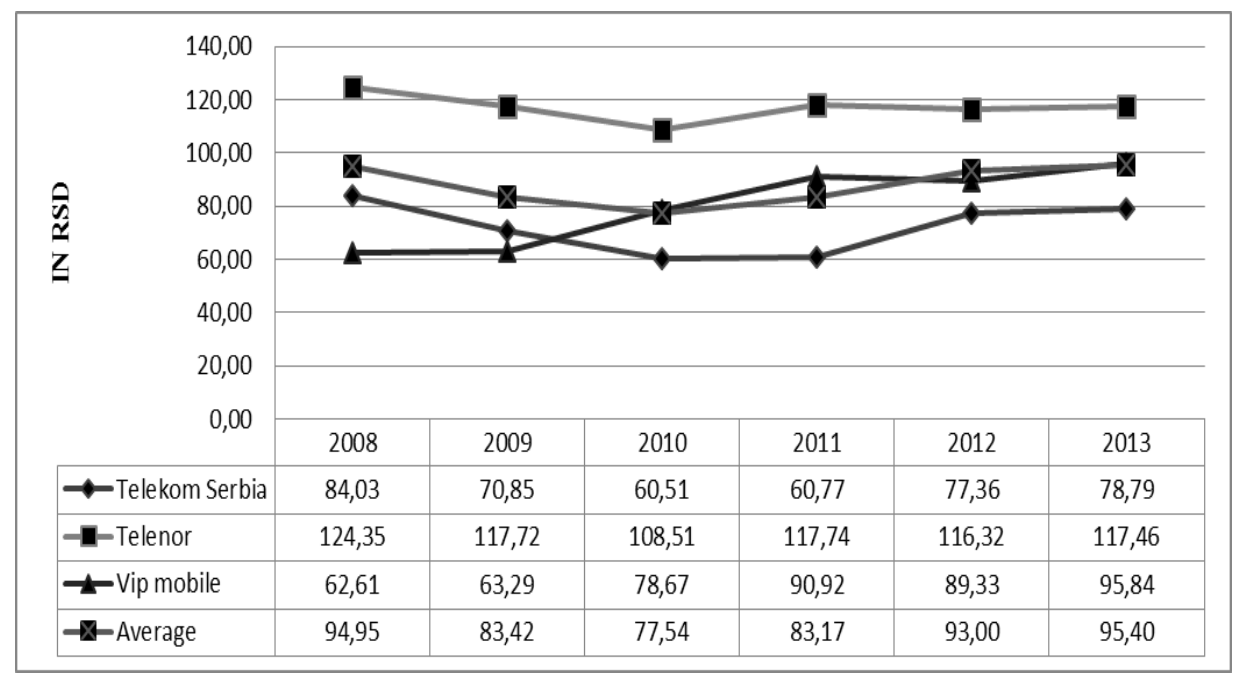

Source: The authors' calculation based on data of Regulatory Agency for Electronic Communications and Postal Services and financial reports of operators, http://www.telekom.rs/Contents/ContentDefault.aspx?temp=0\& sid=1253\& id=1261, http://www.telenor.rs/sr/O-Telenoru/Telenor-u-Srbiji/ Finansijski-pokazatelji/, http://www.vipmobile.rs/o-vipu/press-entar.1076.html? itemId=445

In order to test the mutual dependence of market structure, conduct, and performance of business entities, and test the starting hypothesis, statistical analysis will be used. Statistical analysis relied on the data taken from the publication Review of the telecommunications market in the Republic of Serbia, issued by the Regulatory Agency for Electronic Communications and Postal Services, http://www.ratel.rs. Through linear correlation, we examined the correlation between the market share of operators and the share of operators in the total revenue from mobile telephony.

When analysing these two variables for the time period from 2008 to 2013, by using Pearson's coefficient, it can be concluded that there is a moderately strong, even strong positive correlation (Soldić-Aleksić\&ChroneosKrasavac, 2009).

The highest level of quantitative agreement between variables was in 2008, when Pearson's coefficient equaled 0,937 (Table 6). This points to the high compliance between the level of the market share of operators and their share in total revenue. However, after 2008, the level of correlation decreased, and in 2011 it had the lowest value $(0,685)$. Therefore, the agreement between the 
variables included in the research slightly decreased then increased over time. The results of linear correlation confirmed the correlation between market share of operators and their share in total revenue from mobile telephony.

Table 6 Correlations

\begin{tabular}{|c|c|c|c|c|c|c|}
\hline & 2008 & 2009 & 2010 & 2011 & 2012 & 2013 \\
\cline { 2 - 7 } $\begin{array}{c}\text { Pearson } \\
\text { Correlation }\end{array}$ & 0,937 & 0,899 & 0,820 & 0,685 & 0,788 & 0,747 \\
$\begin{array}{c}\text { Sig. } \\
(2 \text {-tailed) }\end{array}$ & 0,227 & 0,289 & 0,387 & 0,519 & 0,422 & 0,463 \\
\hline $\mathrm{N}$ & 3 & 3 & 3 & 3 & 3 & 3 \\
\hline
\end{tabular}

Source: Authors' calculation

Regression analysis determines the relationship between the two variables: market share of the operator and the share of operators in the total revenue generated by mobile telephony. The regression model points to the extent to which a percentage increase per unit in the value of market share of the operator affects the change in the operator's share in the total revenue from mobile telephony.

Table 7 Linear Regression

\begin{tabular}{|c|c|c|c|}
\hline \multirow[b]{2}{*}{ Model } & \multicolumn{2}{|c|}{ Unstandardized Coefficients } & \multirow[b]{2}{*}{ R Square } \\
\hline & $\mathrm{B}$ & Std. Error & \\
\hline (Constant) & 1,177 & 13,954 & \multirow{2}{*}{0,878} \\
\hline prihod2008 & ,965 & ,360 & \\
\hline (Constant) &,- 106 & 18,478 & \multirow{2}{*}{0,808} \\
\hline prihod2009 & 1,003 & ,489 & \\
\hline (Constant) & $-1,274$ & 26,086 & \multirow{2}{*}{0,673} \\
\hline prihod2010 & 1,038 & ,723 & \\
\hline (Constant) & 2,581 & 34,521 & \multirow{2}{*}{0,469} \\
\hline prihod2011 & ,923 & ,981 & \\
\hline (Constant) & 5,786 & 22,434 & \multirow{2}{*}{0,621} \\
\hline prihod2012 & ,826 & ,645 & \\
\hline (Constant) & 4,867 & 26,080 & \multirow{2}{*}{0,558} \\
\hline prihod2013 & ,854 & ,760 & \\
\hline
\end{tabular}

Source: Authors’ calculation 
In the first observed year (2008), the value of the operators' share in the total revenue generated by mobile telephony increased, on average, by 0.96 when the value of the operators' market share increased by $1 \%$. In the following years, the operators' share in total revenue from mobile telephony grew in the range from 0,8 to 1 when the operators' market share increased by $1 \%$. During the period covered by the analysis (2008-2013), coefficient of determination $\left(\mathrm{R}^{2}\right)$ had a value greater than 0,5 which indicates that a sample was statistically representative.

\section{Conclusion}

Modern markets are predominantly oligopoly structures. The paper presented the analysis of the situation on the mobile telecommunications market in Serbia, examined the conduct of business entities that provide telecommunications services, and analysed the achieved performance of business entities. Measuring the degree of supply concentration pointed to changes in the mobile telecommunications market of Serbia in the period from 2008 to 2013. Analysis of competition in this market was carried out by using the concentration ratio, the Herfindahl-Hirschman Index, the Lorenz curve, and the Gini coefficient. Based on the obtained values of these indicators, it can be concluded that it is a concentrated market. What is more, given the market power and dominance in the market, the existence of participants with significant market power was analysed.

Linear correlation analysis was used to examine the correlation between market share of operators and the share of operators in total revenue from mobile telephony. Calculating Pearson's coefficient in respect of these two variables in the analysed time interval has pointed to a conclusion that there is a moderately strong, even strong positive correlation between them.

Regression analysis revealed a correlation between the two variables: the market share of the operator and the share of operators in the total revenue from mobile telephony. Based on the conducted linear regression it is realised to which percentage increase per unit in the value of market share of operator affects the change in the operator's share in the total revenue from mobile telephony. The results show that in the first observed year (2008), the value of the share of operators in the total revenue from mobile telephony grew by 0,96 on average when the operators' market share increased by $1 \%$. In the following years, the operators' share in the total revenue from mobile telephony grew in the range from 0,8 to 1 when operators' market share increased by $1 \%$. During all the analysed years (2008-2013), the coefficient of determination $\left(R^{2}\right)$ had a value greater than 0,5 , which indicates that a sample was statistically representative. 
Therefore, using statistical methods, linear correlation and regression analyses, the existence of a strong positive relationship between the degree of supply concentration in the market and the level of achieved performance is confirmed.

\section{References}

Andreosso, B. \& Jacobson, D. (2005). Industrial economics and organization: European Perspective. United Kingdom: McGraw-Hill Education.

Bain, J. (1951). Relation of Profit Rate to Industry Concentration: American Manufacturing, 1936-1940. Quartely Journal of Economics, 65 (3), 293-324.

Bajec, J., Stanić, K., Pagliani, P. \& Varga, D. (2006). Srbija - pokazatelji humanog razvoja. Ujedinjene nacije - program za razvoj, Srbija.

Kirzner, I. M. (1973). Competition and entrepreneurship. Chicago: University of Chicago Press.

Kostić, M. (2008). Merenje koncentracije ponude grane. Ekonomski horizonti, 10, (1), 89-108.

Lipczynski, J., Wilson, J. \& Goddard, J. (2005). Industrial Organization: Competition, Strategy, Policy. FT Prentice Hall.

Lipczynski, J., Wilson, J. \& Goddard, J. (2009). Industiral Organisation: Competition, Strategy, Policy. FT Prentice Hall.

McWilliams, A. \& Smart, L. D. (1993). Efficiency v. Structure - Conduct Performance: Implications for Strategy Research and Practice. Journal of Management, doi: 10.1177/014920639301900105

Regulatory Agency for Electronic Communications and Postal Services. (2014). Pregled tržišta telekomunikacija u Republici Srbiji u 2013. godini, http://www.ratel.rs.Accessed 10 October 2014.

Regulatory Agency for Electronic Communications and Postal Services. http://www.ratel.rs.Accessed 10 December 2014.

Samad, A. (2008). Market structure, conduct and performance: Evidence from Bangladesh banking industry. Journal of Asian Economics, 19, Issue 2, 181-193.

Savić, L. B. (2000). Tržišne strukture u jugoslovenskoj industriji. Industrija, 26(1-4), 1-19.

Decision on determining relevant markets, Službeni glasnik Republike Srbije, broj $59 / 11$.

Smirlock, M. (1985). Evidence on the (non) relationship between concentration and profitability in banking. Journal of Money Credit and Banking, 17, 69-83.

Soldić-Aleksić, J. \& Chroneos Krasavac, B. (2009). Kvantitativne tehnike u istraživanju tržišta: Primena SPSS računarskog paketa. Beograd: Centar za izdavačku delatnost Ekonomskog fakulteta u Beogradu.

Stojanović, B. (2012).Mikroekonomija, Niš: Ekonomski fakultet.

Zakon o elektronskim komunikacijama, http://www.paragraf.rs/propisi/zakon_o_elektronskim_komunikacijama.htmlAcc essed 29 September 2014. 
Mobilna telefonija Srbije, http://www.telekom.rs/Contents/ContentDefault.aspx?temp=0\&sid=1253\&id=12 61 Accessed 10 October 2014.

Telenor, http://www.telenor.rs/sr/O-Telenoru/Telenor-u-Srbiji/Finansijski-pokazatelji/ Accessed 10 October 2014.

Vip mobile, http://www.vipmobile.rs/o-vipu/press-centar.1076.html?itemId=445 Accessed 10 October 2014.

\section{MERENJE STEPENA KONKURENCIJE NA TRŽIŠTU MOBILNE TELEFONIJE REPUBLIKE SRBIJE}

Apstrakt: U istraživanju se pošlo od hipoteze da struktura tržišta u velikoj meri opredeljuje ponašanje i nivo ostvarenih performansi privrednih subjekata. Cilj ovog rada je teorijska i empirijska korelaciona analiza između tržišne strukture, ponašanja i performansi privrednih subjekata. U radu je dat analitički osvrt na tržište mobilne telefonije u Republici Srbiji. Korišćenjem različitih pokazatelja (Racio koncentracije, HHI indeks, Lorencova kriva i Džini koeficijent) izmerena je koncentracija ponude na ovom tržištu i sagledana je priroda konkurencije. Pomoću statističkih metoda (linearna korelaciona i regresiona analiza) ispitana je povezanost između varijabli kojima se potvrđuje postojanje jake pozitivne veze između stepena koncentracije ponude na tržištu i nivoa ostvarenih performansi.

Ključne reči: tržišno učešće, koncentracija ponude, SPP paradigma, paradigma efikasnosti, mobilna telefonija

\section{Authors' biographies}

Zorana Kostić is a $\mathrm{PhD}$ student at the Faculty of Economics University of Niš. As a scholar of the Ministry of Education, Science and Technological Development, she is involved in the project "Improving the Competitiveness of Public and Private Sector by networking competences in the process of European integration of Serbia". She works as a volunteer teaching assistant on subject Microeconomics. She worked at Ministry of Finance, Republic of Serbia. She gain international experience through participation in the Program "Willkommen in Deutschland" - Die Regierung Deutschlands (BAYHOST), and study visits at State University of Technology"Shuhov", in Belgorod, Russia and Donetsk National University in Ukraine. She has published more then ten scientific papers as author and coauthor, which were presented at domestic and international conferencies. She was awarded for academic results by Ministry of Education, Science and Technological Development, Fund for young talents and Philip Morris International. She speaks English, German and Russian language. 
Boban Stojanović is a full professor at the Faculty of Economics in Niš. He teaches Microeconomics and Price Theory. He earned his Master's degree and doctorate degree from the Faculty of Economics in Belgrade in 1987 and 1993, respectively. He is Jean Monnet professor, a member of the editorial boards of the Journal of business and economics and Panoeconomicus and the founder and first director of the Center for Multidisciplinary Studies at the University of Niš. He works actively in TEMPUS projects. Stojanovic is President of the Niš Association of Economists, a member on the Executive Committee of SAE. He has been the advisor on several Master's theses and doctoral dissertations. He has participated in many eminent meetings in the country and abroad. Stojanović has published six books and more than 50 scientific and professional papers in leading journals His field of interest includes microeconomics, monopoles, the EU market and competition policy.

Snežana Radukić is an Associate Professor at the Faculty of Economics, University of Nis. She teaches Price Theory and Policy and Microeconomics. She earned Master's degree at the Faculty of Economics, University of Belgrade, in 2003, and a PhD at the Faculty of Economics, University of Niš in 2009. She has published a textbook, three monographs and dozens of scientific papers in journals and conference proceedings of international and national importance. She has participated in numerous conferences, seminars and workshops at home and abroad. She is engaged in the projects of the Ministry of Education, Science and Technological Development of Republic of Serbia since 1999. She has been the advisor on several Master's theses and two doctoral dissertations. The areas of her interest are: microeconomics, state intervention, environmental protection. 